\title{
Inclusive Education For Third Gender Persons In India
}

\author{
Vandita Morarka ${ }^{1}$, Pragya Lodha ${ }^{2}$ \\ ${ }^{1}$ Post graduate student of Public Policy, Mumbai University \& Graduate student of LLB, Government Law College, \\ Mumbai. \\ ${ }^{2}$ Research Assistant, Desousa Foundation, Mumbai. \\ Email: vanditamorarka@gmail.com
}

\begin{abstract}
Background: The research study looks at evaluating perceptions and awareness of students of higher secondary or undergraduate educational level towards the Third Gender and assessing the educational provisions available to meet the third gender needs: varying across infrastructural provisions, educational content, support mechanisms, teaching delivery and language inclusivity.

Methodology: The present primary research was carried out with 100 participants within the age range of 16-26 years through the means of an online survey under convenient sampling method. The median age of respondents was found to be 21years. The surveyed population included youth from urban India, based in cities like Mumbai, Delhi, Chennai, Hyderabad, Manipal and Indore. The survey comprised of 31 questions that were in the format of binary choice (Yes / No), 5-point rating scale (ranging from very poor to excellent) and open ended questions.

Results: The findings of research highlight a strong lack of awareness amongst students regarding to needs and rights of third gender persons as well as a severe lack of educational provisions by institutions to meet Third Gender needs on all aspects covered. A resounding 100\% said that they think that the education policy must address third gender issues of education access and learning processes. Eighty nine percentage $(89 \%)$ of the respondents felt that the government was not doing enough to tackle the concerns of education of the third gender community in India.

Conclusion: Further work and research is needed to improve and strengthen and improve the educational policy for third gender individuals. This must be taken at a local and central level alike.
\end{abstract}

Key Words: Transgender persons, Third Gender, Inclusive Education, Indian Context

(Paper received $-22^{\text {nd }}$ November 2016, Peer review completed $-8^{\text {th }}$ January 2017 , Accepted $-6^{\text {th }}$ March 2017)

\section{INTRODUCTION}

Transgender or the third gender is generally described as an umbrella term for persons whose gender identity does not conform to their biological sex. For the purpose of this study and for comprehensive understanding of the various alternate gender identities, we operationally define Third Gender persons as, "persons that do not identify with male or female gender identities". This is done keeping in mind the complex nature of gender identities in reality and the lack of specific instructions for each varied gender in law or policy in India [1].

The 2014 first-ever official census of third gender persons (TG) in the country, except including Kerala, showed numbers standing at 490,000, of these 55,000 were children. Activists state that actual numbers are much higher as several do not want to identify themselves as the third gender [2]. In the landmark National Legal Services Authority v. Union of India [Writ Petition (Civil) No. 400 of 2012] - on April 15 
2014, India's Supreme Court recognized the right of Third Gender persons to identify as another gender. The ruling required the government to form distinct quotas for transgender persons in employment and education, directing the government to take affirmative action to improve the status of transgender persons and provide them with opportunities that they have been denied up to now [3].

Some educational developments following the judgment:

1. Ministry of Human Resource Development directive to States \& UT's for inclusion of third gender children among socially and educationally backward classes for admission in educational institutions under the Sarva Shiksha Abhiyan (SSA); UGC circular issued including Third Gender under the various scholarship and fellowship schemes of the Commission;

2. Several institutes have taken progressive action; appoint third gender persons to educational positions $^{1}$ and encouraging Third Gender education.

In 2016, A Private Member Bill was introduced by Tiruchi Siva for Third Gender person rights which included provisions for Third Gender reservations in educational institutes and scholarships. The Private Member Bill though lies pending as The Transgender Persons (Protection of Rights) Bill, 2016, was introduced as a Government Bill later and also stands pending approval. This Government Bill is severely lacking in any provisions for affirmative action or specific provisions for addressing educational needs of the Third Gender along with having several concerns with reference to the definitions and terminology used [4].

Internationally efforts are being made to meet needs of Third Gender persons at educational institutions which are more comprehensive and all encompassing. In our survey we examine the availability of a combination of facilities provided for at educational institutes that include existing Indian legal provisions and international best practices. The literacy levels amongst the Third Gender are lower than the national average, especially startlingly so in the higher secondary and undergraduate education section. This study was conducted to understand the perception of the population of the younger bracket towards the third gender and address education gaps for the third gender at the higher secondary and undergraduate college level in urban India by assessing available amenities for Third Gender students at these institutions. An analysis of existing policy and legal frameworks has been undertaken to assess the provisions that institutions must mandatorily provide, whereas international practices are looked at to understand what best practices must be undertaken to create provisions of a more inclusive educational structures for better meetings the needs and aspirations of Third Gender persons. Aspects of policy and educational infrastructure have been covered in the study to gauge the level of awareness and presence of available facilities sensitive to the requirements of the third gender [5-6].

\section{METHODOLOGY}

The present primary research was carried out with 100 participants within the age range of 16-26 years through the means of an online survey under convenient sampling method. The median age of respondents was found to be 21years. The surveyed population included youth from urban India, based in cities like Mumbai, Delhi, Chennai, Hyderabad, Manipal and Indore. The form was filled by those who were currently enrolled in an educational institution for higher secondary education or undergraduate studies ( $11^{\text {th }}$ grade onwards to graduation) or had been thus enrolled in one till July 2014 at least. The survey comprised of 31 questions that were in the format of binary choice (Yes / No), 5-point rating scale (ranging from very poor to excellent) and open-ended questions. 


\section{RESULTS AND DISCUSSION}

Findings indicate that only $10 \%$ of respondents had classmates who were not cis-gender.

\section{Perceptions}

The perception towards the third gender as classmates and friends was found to be accepting by majority of respondents. However, there 5\% respondents expressed that the idea of a Third Gender classmate made them feel unsafe and $8 \%$ indicated that they would not want to be friends with someone belonging to the third gender while only $5 \%$ had reported that gender played a role in determining their friendships. Eighty one percentage (81\%) of respondents stated their self awareness of Third Gender needs and rights as less than or equal to 3 , on a 5 point scale: 1 being very poor and 5 being excellent.

Here we examined available facilities to address Third Gender concerns in higher secondary and undergraduate educational institutions, including both infrastructural facilities and the curriculum, manner of teaching as well as soft power based programs for creating awareness and sensitization. We look at both, provision of measures as implementation of government policy and regulations and any additional measures that may have been taken by the institution by itself.

\section{Educational Infrastructure}

In terms of infrastructure, focus is placed more on physical provisions in the institute. $26 \%$ said they had Third Gender or Other as an option on admission forms, while $11 \%$ said they had these options on other college documentation; sadly lacking also the awareness of such provisions in the respondents, where $42 \%$ and $53 \%$ said they were unaware respectively. This indicative of the lack of knowledge of basic legal provisions for Third Gender rights and a marked last of interest in knowing about such provisions and their implementation in their own educational institutions.

\section{Beyond government policy}

Only 1 respondent stated that there was a reservation quota for the Third Gender at their institute, 35\% of respondents were unaware of any such policy and 64\% said that their college did not have any such reservation policy. Fifty four percent (54\%) said their institution had no scholarship provisions for the Third Gender and $46 \%$ were unaware of any such provision. While the current Transgender Persons (Protection of Rights) Bill, 2016 does not speak of any reservations or scholarship - the NALSA judgment had clearly pointed at providing boosters for educational and employment attainment for the Third Gender. $95 \%$ respondents stated that there were no gender neutral washrooms available, only $2 \%$ saying that they had such facilities on campus. $61 \%$ respondents said they did not have gender neutral infrastructural facilities, with $12 \%$ saying they did have such facilities, whereas only $2 \%$ had mentioned availability of gender neutral washrooms - showing a amount of unawareness of what gender neutral facilities comprise of.

$75 \%$ had said they had counseling facilities at their institutes, only $35 \%$ said that these facilities encouraged safe spaces for discussions on gender and sexuality. While $62 \%$ respondents had stated that their educational institute had personnel or committee to address concerns of harassment or bullying, only $8 \%$ said these bodies also deal with issues of Third Gender harassment or bullying. As large as $84 \%$ respondents rated the quality of infrastructure to meet the needs of Third Gender students as less than or equal to 3 , on a 5 point scale. These factors combined highlight a lack of initiative on the part of educational institutions to engage in inclusive educational practices or make provisions for an environment and structural set up that promotes and supports the educational aspirations of individuals of the Third Gender. There has been no independent effort from most institutions to also incorporate policies within their own management to aid the educational development of Third Gender students.

\section{Educational Content}

It was found that only $41 \%$ respondents had had gender included as a topic of study through the course of their formal education and $69 \%$ of the respondents had not been exposed to any kind of educational study material on third gender or gender plurality. Hence, $28 \%$ of those who had even received any gender 
education had not received any information on gender plurality or third gender, this severe lack in inclusivity in imparting education forms a basis for future lack of awareness and interest in the rights and provisions for Third Gender.

\title{
Language Inclusivity
}

A share of $62 \%$ respondents expressed that their teachers used gendered language while teaching. This finding is a reflection of poor sense of training of teachers itself regarding the existing literature on gender neutral language and terminologies, such language can become a barrier to inclusivity of Third Gender students in the classroom. This trickles down to children being taught a highly gendered language that is insensitive to the needs of varied gender identities. A huge percent of $87 \%$ respondents rated the language inclusivity used at their educational institutions towards Third Gender less than or equal to 3, on a 5 point scale.

\begin{abstract}
Awareness
Our analysis shows that $69 \%$ of the respondents were unaware of the legal rights and status of the third gender India. The majority of the remaining 31\% were either only aware of the existing NALSA judgment or Section 377 of Indian Penal Code ${ }^{2}$ or the fact that the third gender are subject to unequal treatment, without any in depth knowledge of any. Very few expressed a detailed understanding of the third gender status in India and the need to have a stronger rights framework in order to provide for equality in law for the Third Gender. 26\% respondents actually rated their perception of the educational status of Third Gender individuals in India 4 or 5 on a 5 point scale. Only $14 \%$ respondents said they were taught of the legal changes in the rights and status of the Third Gender at their educational institute and $15 \%$ respondents said that their institute carries out programs to create awareness about Gender \& the Third Gender, others were not exposed to any sort of training or awareness creation by their educational institutions. $88 \%$ respondents rated the attempts of their educational institutions to increase sensitivity to and create awareness of Third Gender less than or equal to 3, on a 5 point scale. Most students also have low awareness of provisions for Third Gender students in their own institutes brought on by lack of any exposure to related material. Additionally when asked about the awareness of employment engagements of the third gender, $69 \%$ of the respondents confirmed that they knew of Third Gender persons engaged only in beggary and prostitution. Despite this, $8 \%$ people responded saying that the benefits given by the government to the third gender to access education are extra privileges and thus, should be denied.
\end{abstract}

A resounding $100 \%$ did say that they think that the education policy must address Third Gender issues of education access and learning processes. $89 \%$ of the respondents felt that the government was not doing enough to tackle the concerns of education of the Third Gender community in India.

\section{SUGGESTIONS FROM RESPONDENTS}

Our last question asked for suggestions or comments with reference to education of Third Gender persons. Several expressed the need for equal treatment, better implementation of laws, more inclusive educational practices, better infrastructural facilities to be made available and more chances of employment to be created. Surprisingly a lot of responses seemed to stress on how being of the Third Gender wasn't the fault of the person, in essence implying in several places that they considered being of a gender apart from male or female an aberration. There was a constant 'othering' of Third Gender persons in the suggestions mentioned and an expressed need to first sensitize males and females as well as to first train Third Gender persons separately to then have them join mainstream society. These suggestions clearly highlight subconscious biases held amongst most people on how they view Third Gender persons and makes a strong case for creating awareness about issues and needs pertaining to the Third Gender.

\section{KEY POINTS}


Several key points came to the surface as a consequence of results obtained and they are enlisted as below:

1. Severe lack of awareness of Third Gender rights, needs, policy provisions etc., amongst the youth student population;

2. Lack of commitment from educational institutions to follow legal provisions for Third Gender enrolment;

3. No infrastructural provisions or care facilities made at educational institutions to meet the needs of Third Gender students;

4. No initiative on the part of educational institutions to create curriculum, engage students or train teachers in a manner so as to encourage inclusivity.

5. Want on part of students for an inclusive educational policy and more action from the government to better meet the educational needs of Third Gender students.

These issues of neglect and low understanding are key to assessing the vast observed lacunae in the understanding of gender identity. Gaps in understanding originate in gaps in educational content and delivery and lead to a skewed understanding of the students on gender issues. Years of lack of educational opportunities reflects in the lack of employment opportunities available and hence creates an urgent need to build educational systems that factor in these diverse needs to provide equal opportunity for all and the chance of attainment of full potential of all students, while being sensitive to needs of all genders.

\section{PROPOSED SOLUTIONS}

Keeping in mind the results and findings obtained through this study, a need for further implementable solutions was felt necessary, the co-authors, to be discussed as a part of the paper. Following below are the proposed solutions,

1. Allow for reservations and scholarship provisions for Third Gender persons in educational institutes. This has been looked at in the NALSA judgment and in the Private Member Bill on Third Gender rights of 2016 as well.

2. Make it mandatory for institutions to have gender neutral provisions, including but not limited to the following: washrooms, changing rooms, common room areas, uniforms, documentation, sporting activities, counseling and harassment resolution centers.

3. Introduce compulsorily at a lower educational level of formal education: gender education that is inclusive of gender and sexual plurality, compulsory modules on laws and legal changes in the nation, language training that is inclusive.

4. Undertake compulsory training or refresher programs for all teachers that encompass teachings on gender, language inclusivity and increasing sensitivity towards various gender identities.

5. Undertake informational awareness campaigns across educational institutions.

6. Compulsorily train mental health professionals and personnel dealing with complaints of harassment and bullying on issues of gender plurality and inclusiveness.

7. Create skill development programs for mature Third Gender students to aid their transition to gaining employment sooner while also providing options of standard educational programs.

8. Building of a National Education Policy where these solutions find the sanction of law for their actual implementation by educational institutes.

\section{REFERENCES AND RECOMMENDED READING}

1. Deutsch FM. Undoing gender. Gender Soc 2007;21(1):106-27.

2. Nagarajan R. First count of third gender in census: 4.9 lakh. The Times of India. $201430^{\text {th }}$ May.

3. Afshar H. Women and empowerment: Illustrations from the Third World. Springer; 2016.

4. Gangoli G. Indian feminisms: Law, patriarchies and violence in India. Routledge; 2016.

5. Stromquist NP, Monkman K, editors. Globalization and education: Integration and contestation across cultures. R\&L Education; 2014.

6. Corno L, Anderman EM. Handbook of educational psychology. Routledge; 2015.

7. Carnoy M, Samoff J. Education and social transition in the Third World. Princeton University Press; 2014. 
8. Klein SS, Richardson B, Grayson DA, Fox LH, Kramarae C, Pollard DS, Dwyer CA, editors. Handbook for achieving gender equity through education. Routledge; 2014.

9. Banks JA. Cultural diversity and education. Routledge; 2015.

10. Walker S, Barton L. Gender, Class and Education (Routledge Revivals). Routledge; 2013.

11. Vanita R. Queering India: Same-sex love and eroticism in Indian culture and society. Routledge; 2013.

12. Stromquist NP. Women in the Third World: An encyclopedia of contemporary Issues. Routledge; 2014.

13. Jayawardena K. Feminism and nationalism in the Third World. Verso Books; 2016.

14. Connell RW. Gender and power: Society, the person and sexual politics. John Wiley \& Sons; 2014.

$* * * * * * * * * * * * * * * * * * * * * * * * * * * * *$

Acknowledgements - Nil

Source of Funding - Nil

Conflict of Interest - Nil 